\title{
STUDI LINGKUNGAN PENGENDAPAN DAN DIAGENESIS BATUAN BERDASARKAN ANALISIS PETROGRAFI DI DAERAH SUKOLILO, PATI, JAWA-TENGAH
}

\author{
Wahyu Budi Kusuma ${ }^{1 *}$, Kalimi $^{2}$ \\ ${ }^{1,2}$ Pusat Pengembangan Sumber Daya Manusia Minyak dan Gas Bumi, Cepu
}

\begin{abstract}
ABSTRAK
Batupasir Formasi Ngrayong merupakan reservoir penting di cekungan migas jawa bagian timur-utara sedangkan Formasi Bulu umumnya memiliki fungsi sebagai akuifer di daerah penelitian. Kualitas akuifer dan reservoir berupa porositas dan permeabilitas dapat dipengaruhi oleh proses diagenesis. Penelitian ini bertujuan untuk menentukan lingkungan pengendapan dan proses diagenesis yang terjadi pada batuan di Formasi Ngrayong dan Formasi Bulu. Batupasir sebagaimana batuan sedimen pada umumnya mengalami proses diagenesis berupa kompaksi, sementasi, dan pelarutan, sedangkan batuan karbonat proses diagenesisnya sangat bervariasi tetapi yang terpenting adalah proses pelarutan dan rekahan sebagai pembentuk porositas. Dari hasil analisis petrografi dapat diketahui bahwa lingkungan pengendapan Formasi Ngrayong adalah neritik tengah-neritik dalam sedangkan Formasi Bulu diendapkan di lingkungan inner shelf. Proses diagenesis yang terjadi berupa kompaksi, sementasi, pelarutan dan mikritisasi.
\end{abstract}

Kata kunci: Fm Ngrayong, Fm Bulu, petrografi, lingkungan pengendapan, diagenesis

\begin{abstract}
Sandstones of Ngrayong Formation are an important reservoir in the north-east Java basin while the Bulu Formation generally functions as an aquifer in the study area. The quality of aquifers and reservoirs in the form of porosity and permeability can be influenced by the diagenesis process. This study aims to determine the depositional environment and diagenesis processes that occur in rocks of Ngrayong Formation and Bulu Formation. Sandstones as sedimentary rocks generally undergo diagenetic processes consisting of compaction, cementation, and dissolution, while carbonate rocks diagenesis processes are very varied but the most important is the process of dissolving and fracturing as forming porosity. From the results of the petrographic analysis, it can be seen that the depositional environment of the Ngrayong Formation is inner-neritic to middle-neritic while the Bulu Formation is deposited in the inner shelf environment. The diagenesis process that occurs is compaction, cementation, dissolution and micritization.
\end{abstract}

Keywords: Ngrayong Formation, Bulu Formation, petrographic, depositional environment, diagenesis

\section{PENDAHULUAN}

Reservoir merupakan unsur yang berperan penting dalam penampungan minyak dan gas bumi. Kualitas reservoir penting untuk kita ketahui agar kita dapat menentukan apakah suatu wilayah memiliki potensi hidrokarbon untuk dikembangkan atau tidak. Kualitas reservoir berupa porositas dan permeabilitas dapat dipengaruhi oleh proses diagenesis. Oleh karena itu pada penelitian ini analisa petrografi diarahkan pada proses diagenesis dan lingkungan pengendapan dari suatu reservoir.

Batupasir dan batuan karbonat merupakan akuifer dan reservoir hidrokarbon yang email:wbudik@esdm.go.id 
banyak dijumpai di dunia. Di Indonesia, Formasi Ngrayong dan Formasi Bulu terkenal sebagai akuifer dan juga reservoir hidrokarbon. Batupasir Formasi Ngrayong merupakan reservoir penting di cekungan migas jawa bagian timur-utara sedangkan Formasi Bulu umumnya memiliki fungsi sebagai akuifer di daerah penelitian.

Batupasir dan batuan karbonat memiliki proses diagenesis yang berbeda. Batupasir sebagaimana batuan sedimen pada umumnya mengalami proses diagenesis berupa kompaksi, sementasi, dan pelarutan, sedangkan batuan karbonat proses diagenesisnya sangat bervariasi tetapi yang terpenting adalah proses pelarutan dan rekahan sebagai pembentuk porositas. Batuan karbonat merupakan batuan sedimen yang umumnya diendapkan di lingkungan laut dangkal. Fasies batuan karbonat bervariasi baik secara vertikal maupun lateral, hal ini disebabkan karena bervariasinya proses selama pembentukannya baik yang terkait dengan diagenesis maupun deformasi.

Penelitian kali ini difokuskan pada analisa petrografi untuk menentukan lingkungan pengendapan dan proses diagenesis yang terjadi. Tujuan dari penelitian ini adalah:

- Identifikasi komposisi batuan dan tekstur pengendapan untuk penentuan nama batuan.

- Identifikasi mikrofasies dan proses-proses diagenesis untuk menafsirkan lingkungan pengendapan dan lingkungan diagenesis.

Lokasi penelitian secara administratif berada di Kecamatan Sukolilo, Kabupaten Pati, Jawa Tengah. Posisi geografis daerah penelitian adalah 6053'1,13" - 6 57'59,94" Lintang Selatan (LS) dan $110^{\circ} 55^{\prime} 4,80^{\prime \prime}$ - 11057'18.45” Bujur Timur (BT)

\section{TINJAUAN PUSTAKA}

Berdasarkan klasifikasi fisiografi Jawa (Bemmelen, 1949), daerah Sukolilo, Pati terletak pada jalur pegunungan Kendeng (antiklinorium Bogor - Serayu Utara - Kendeng). Tepatnya pada Pegunungan Kendeng Utara yang merupakan perbukitan lipatan dengan sumbu membujur dari Barat - Timur .

Stratigrafi di daerah pemetaan menurut Pringgoprawiro (1983) masuk dalam Formasi
Ngrayong, Formasi Bulu dan Aluvium. Menurut penelitian terdahulu Formasi Ngrayong disusun oleh perselingan napal, batupasir, dan batulempung dengan sisipan batugamping pasiran. Satuan ini sebelumnya disebut sebagai Batugamping Orbitoid (Orbitoiden Kalk) oleh Trooster (1937) dalam Kadar \& Sudijono (1994); Anggota Ngrayong Formasi Tuban (Koesoemadinata, 1978); dan diusulkan menjadi Formasi Ngrayong oleh Kadar (1986), yang dapat disebandingkan dengan Anggota Bawah Formasi Tuban. Menurut Budiman (1976, dikutip dari Suwarti dan R. Wikarno, 1992) Formasi Ngrayong ini berumur Miosen Tengah (N9 - N12).

Formasi Bulu disusun oleh batugamping. Satuan ini dikenal pula dengan sebutan Platen Complex (Trooster, 1937) dalam Kadar \& Sudijono (1994), diusulkan menjadi Formasi Bulu oleh Pringgoprawiro (1983) dengan lokasi tipe di Bukit Gendruwo, Kecamatan Bulu. Formasi ini diperkirakan terbentuk di lingkungan pengendapan laut dangkal pada Kala Miosen Akhir, Zona Tf1-Tf3 (Budiman, 1976).

Menurut Haryono (2001), bukit kars dan mintakat epikars mampu menyimpan air hingga tiga atau empat bulan setelah berakhirnya musim penghujan, sehingga sebagian besar sungai bawah tanah dan mata air mengalir sepanjang tahun dengan kualitas baik. Mata air epikars dikenal mempunyai kelebihan dalam hal:

1. Kualitas air yang baik dan jernih, karena sedimen yang ada sudah terperangkap dalam material isian atau rekahan

2. Debit air yang stabil

3. Mudah untuk dikelola.

\section{METODE PENELITIAN}

Metode penelitian yang digunakan dalam penelitian ini ada 2 (dua) yaitu:

1. Metode Deskriptif

Metode deskriptif ini terdiri dari studi pustaka dan studi kasus. Studi pustaka dilakukan dengan cara mengumpulkan literatur dan mengolah data dan informasi dari berbagai literatur tersebut. Sedangkan studi kasus dilakukan untuk menggambarkan secara rinci mengenai stratigrafi dan karakteristik batuan. 
2. Metode Analisis Petrografi

Analisis petrografi dilakukan terhadap 7 sampel batuan, 4 (empat) sampel dari Formasi Ngrayong dan 3 (tiga) sampel dari Formasi Bulu. Tujuan dari analisis ini untuk melihat komposisi material pembentuk batuan (fragmen, matrik dan semen), hubungan antar butir serta porositas batuan serta proses diagenesis yang terjadi.

\section{HASIL DAN PEMBAHASAN}

\section{A. Kondisi Geologi}

Daerah penelitian berada pada punggung perbukitan batugamping yang merupakan perbukitan homoklin dengan arah kemiringan relatif ke utara. Geomorfologi daerah Sukolilo merupakan komplek perbukitan kars yang dicirikan dengan kenampakan bukit-bukit kerucut (conical hills), cekungan hasil pelarutan (dolina), lembah-lembah aliran sungai yang membentuk mulut gua (sinkhole).

Berdasarkan pada interpretasi peta rupa bumi, analisa morfologi dan pengamatan lapangan, bentuk-bentuk bentang alam daerah penelitian didominasi oleh bentuk morfologi perbuki$\tan$ dan dataran dengan elevasi tertinggi adalah $358 \mathrm{~m}$ dan terendah $75 \mathrm{~m}$.

Sungai-sungai berpola subdendritik, dengan tingkat stadium muda hingga dewasa, dicirikan oleh adanya lembah-lembah berbentuk $\mathrm{V}$ hingga U serta di beberapa tempat dijumpai proses erosi ke hulu.

Sungai yang mengalir dibagi menjadi dua zona arah aliran yaitu Utara dan selatan. Sungaisungai tersebut muncul dari rekahan batugamping sehingga termasuk dalam tipe mata air rekahan. Dibagian utara, mata air muncul di daerah berelief rendah hingga dataran dengan ketinggian berkisar antara 20-100 mdpl sedangkan di bagian selatan muncul pada ketinggian 100-350 mdpl.

Proses karstifikasi di daerah ini masih berlanjut dibuktikan dengan ditemukannya sungai bawah permukaan yang keluar sebagai aliran permukaan antara lain di Gua Wareh dan Gua Pancuran. Fenomena ini menunjukkan bahwa perbukitan batugamping merupakan daerah resapan air (recharge area). Sungai bawah permukaan bersifat parenial artinya terus mengalir dalam debit yang konstan sepanjang tahun.

Kemiringan lereng berkisar antara $0 \%$ hingga $70 \%$ dan di beberapa tempat dijumpai gawirgawir vertikal. Setempat dijumpai longsoran dan jatuhan batu.

Tata guna lahan adalah persawahan, perkebunan dan pemukiman penduduk. Mata air permanen banyak dijumpai, yang merupakan sumber utama air bersih bagi penduduk setempat.

Stratigrafi daerah penelitian dari yang berumur tua hingga muda adalah:

- Satuan Perselingan Batulempung/Lanau Batugamping dan Batupasir gampingan (Fm Ngrayong). Satuan ini tersebar di bagian selatan daerah penelitian dan setempat dijumpai di bagian utara. Secara megaskopis kenampakan batulempung dan lanau bersifat non-gampingan adalah: berwarna abu-abu kehijauan sampai hitam, lunak - teguh, terdapat konkresi besi, pyrit, dan batulempung. Konkresi batulempung berwarna abu-abu.

- Satuan Batugamping, Secara megaskopis, Satuan Batugamping dibedakan menjadi dua yaitu batugamping berlapis dan batugamping masif yang dicirikan oleh permukaannya yang berongga dan kadang kristalin.

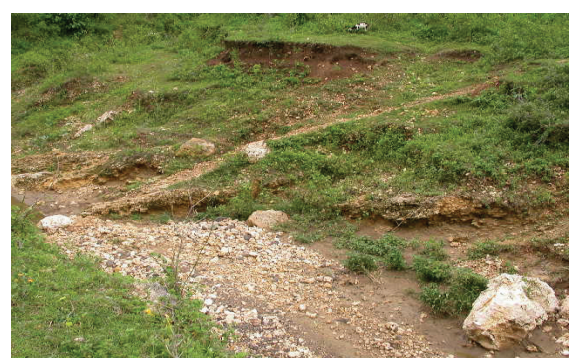

Gambar 1. Perselingan batulempung dan batugamping di Kali Sat

Batugamping berlapis berwarna putih abuabu sampai kecoklatan, berlapis tipis, dengan ketebalan dapat mencapai $70 \mathrm{~cm}$, secara umum mempunyai jurus berarah $\mathrm{N} 220^{\circ} \mathrm{E}-\mathrm{N} 260^{\circ} \mathrm{E}$ dengan kemiringan perlapisan berkisar antara $5-20^{\circ}$ (Gambar 2), setempat dijumpai jejak kayu yang telah terkristalisasi (Gambar 3). 


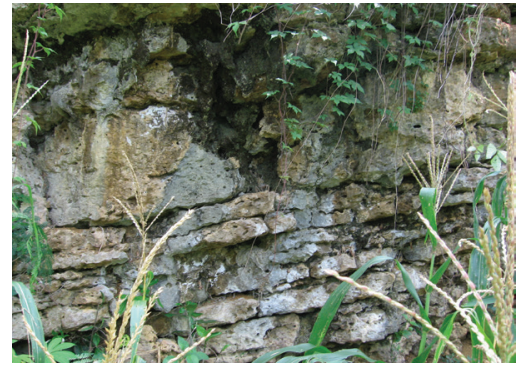

Gambar 2. Singkapan batugamping berlapis di Daerah Goa Banteng

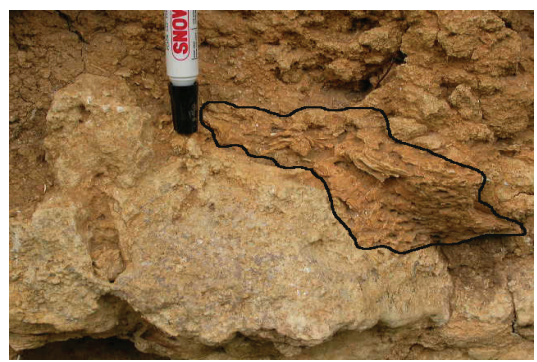

Gambar 3. Jejak kayu yang telah terkristalisasi pada batugamping berlapis

Sedangkan batugamping masif dijumpai pada bagian atas bukit-bukit kerucut dengan bagian atas sebagian telah mengalami pelarutan dan menunjukkan ciri fisik yang khas berupa rongga (Gambar 4). Pada bagian atas litologi batugamping masif kadang dijumpai gamping kristalin yang berkembang dengan baik. Satuan Batugamping ini merupakan bagian dari Formasi Bulu tersebar di bagian utara dari daerah penelitian membentuk bukit-bukit kerucut dengan lereng yang terjal.

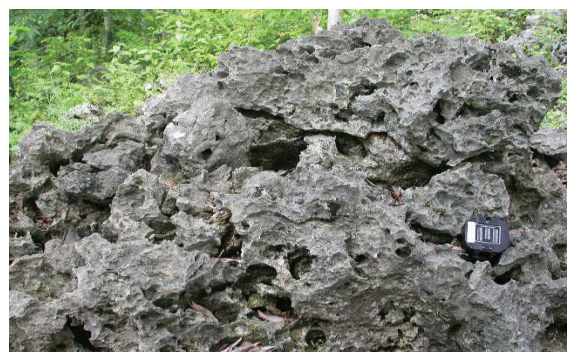

Gambar 4. Batugamping masif dengan kenampakan berongga pada bagian atasnya
- Aluvium, Merupakan endapan permukaan yang pembentukannya berlangsung terus hingga saat ini, terdiri dari material lepas berukuran lempung sampai kerakal, berupa endapan sungai dan rawa. Dalam kaitannya dengan penelitian, rencana area untuk penambangan lempung termasuk dalam satuan litologi aluvium dengan sebaran luas di dataran pada bagian utara daerah penelitian. Dari hasil pengujian X-ray diperoleh kandungan unsur yang dominan dari batulempung dan lanau pada satuan ini adalah $\mathrm{SiO} 2$ (36\%-56\%), Al2O3 (10\%-23\%), Fe2O3 (4\%-8\%), $\mathrm{CaO}$ (2\%-12\%), dan LOI (13\%-22\%) sedangkan $\mathrm{Na} 2 \mathrm{O}$ hanya dijumpai di beberapa contoh batuan (Tabel 3.2).

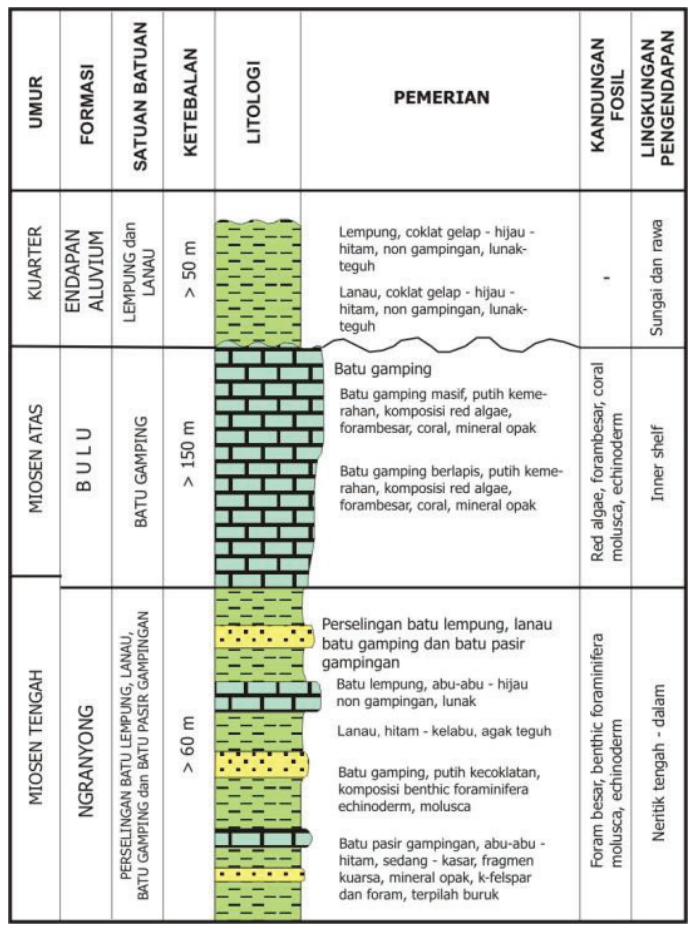

Gambar 5. Kolom stratigrafi daerah penelitian 
Tabel 1. Hasil Uji Geokimia X-Ray Batulempung Satuan Aluvium

\begin{tabular}{|c|c|c|c|c|c|}
\hline $\mathrm{No}$ & $\begin{array}{c}\mathrm{SiO}_{2} \\
(\%)\end{array}$ & $\begin{array}{c}\mathrm{Al}_{2} \mathrm{O}_{3} \\
(\%)\end{array}$ & $\begin{array}{c}\mathrm{Fe}_{2} \mathrm{O}_{3} \\
(\%)\end{array}$ & $\begin{array}{c}\mathrm{CaO} \\
(\%)\end{array}$ & $\begin{array}{c}\text { LOI } \\
(\%)\end{array}$ \\
\hline $\mathrm{X}-4$ & 54.08 & 18.95 & 8.11 & 2.70 & 13.92 \\
$\mathrm{X}-5$ & 44.13 & 18.55 & 7.07 & 11.19 & 16.67 \\
$\mathrm{X}-6$ & 53.32 & 17.49 & 7.23 & 4.38 & 14.81 \\
$\mathrm{X}-7$ & 51.45 & 17.77 & 7.36 & 5.93 & 14.03 \\
$\mathrm{X}-9$ & 51.16 & 22.08 & 6.31 & 3.99 & 13.76 \\
$\mathrm{X}-10$ & 55.24 & 18.87 & 7.84 & 2.94 & 13.18 \\
$\mathrm{X}-11$ & 36.17 & 12.27 & 4.19 & 18.15 & 21.04 \\
$\mathrm{X}-14$ & 50.67 & 16.64 & 6.80 & 7.59 & 14.48 \\
$\mathrm{X}-15$ & 46.38 & 10.85 & 5.69 & 15.01 & 11.44 \\
\hline
\end{tabular}

\section{B. Analisis Petrografi}

Analisis petrografi dilakukan untuk mengidentifikasi karakteristik batuan yang meliputi aspek komposisi (mineralogi, biota, masa dasar dan semen), tekstur pengendapan dan proses-proses diagenesis yang telah berlangsung. Pada analisis petrografi ini, penamaan batupasir menggunakan klasifikasi Pettijohn (1987) (Gambar 6).

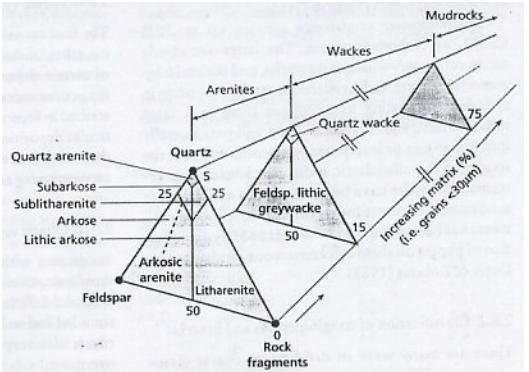

Gambar 6. Klasifikasi batupasir (Pettijohn, 1987)

Penamaan batuan bertekstur halus menggunakan klasifikasi Tucker (1991) (Gambar 7).

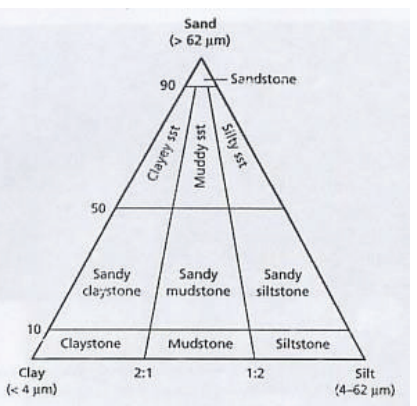

Gambar 7. Klasifikasi batuan sedimen kalstik bertekstur halus (Tucker, 1991).

Klasifikasi porositas batuan karbonat menggunakan klasifikasi Choquete and Pray (1970) (gambar 8).

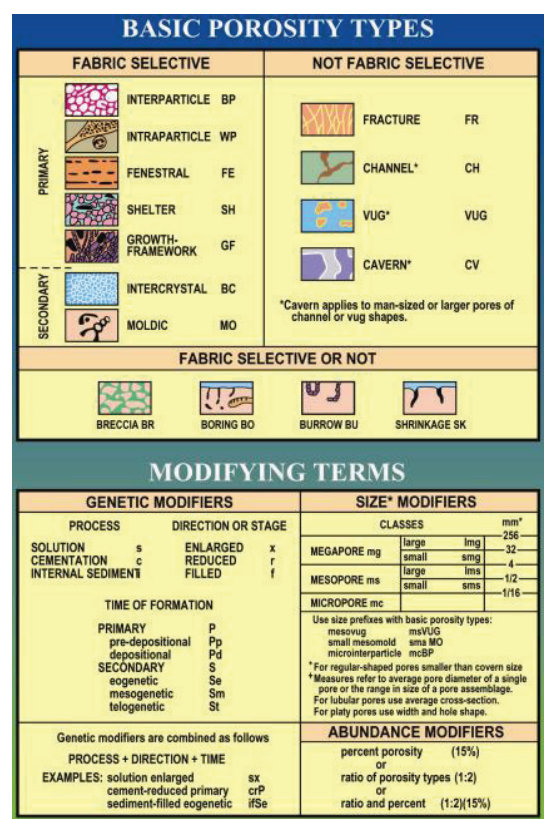

Gambar 8. Tipe-tipe porositas (Choquete and Pray, 1970)

Penamaan fasies batuan karbonat menggunakan klasifikasi Dunham (1962) yang didasarkan pada ciri tekstur pengendapan dan komposisi batuan (Gambar 9).

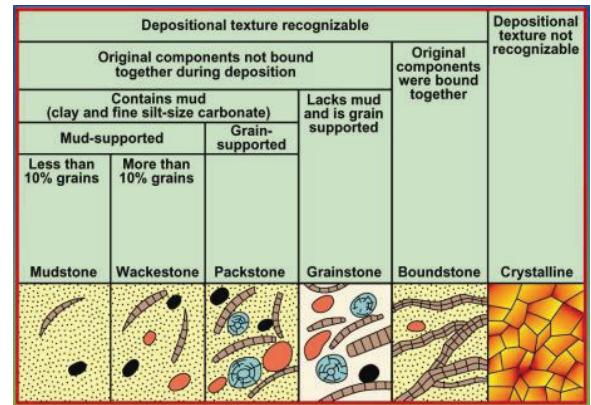

Gambar 9. Klasifikasi batuan karbonat menurut tekstur pengendapan (Dunham, 1962)

Analisa diagenesis dan lingkungan diagenesis batuan karbonat menggunakan klasifikasi Tucker \& Wright (1990) (Gambar 10). 


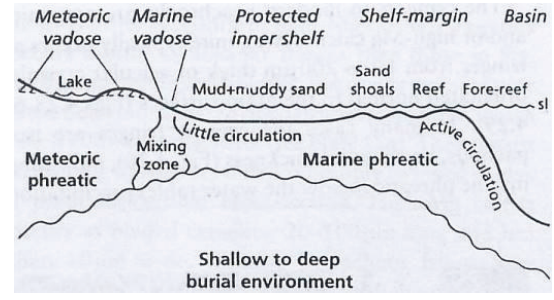

Gambar 10. Lingkungan dan Proses Diagenesis Batuan Karbonat (Tucker \& Wright, 1990).

Klasifikasi lingkungan pengendapan batuan sedimen menggunakan klasifikasi Tipsword, dkk (1966) (Gambar 11)

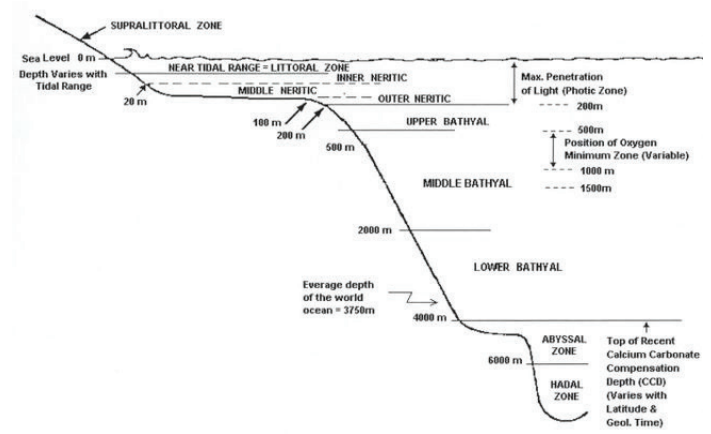

Gambar 11. Klasifikasi Lingkungan Pengendapan Laut menurut Tipsword dkk, 1966.

Sampel batuan diambil dari satuan batuan yang berbeda baik dari singkapan maupun inti bor yang kemudian dipotong, diasah dan dipreparasi menjadi sayatan tipis standar (tanpa analisa noda dan blue dye) dengan ketebalan $0,03 \mathrm{~mm}$. Sayatan tipis ini dianalisis petrografi detil dengan menggunakan mikroskop polarisasi Nikon.

\section{Fm Ngrayong}

Hasil analisis petrografi terhadap sayatan tipis contoh batuan dari Desa Tompegunung tepatnya pada contoh bor inti BEG 6 (P10) (Gambar 12).

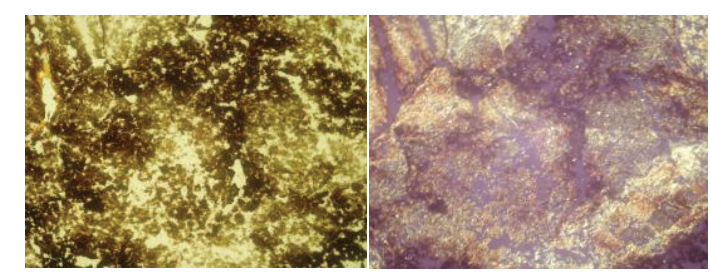

\begin{tabular}{|c|c|}
\hline // nicol & X nicol \\
\hline Sayatan Claystone bertekstur klastik, terpilah \\
baik, kemas tertutup, dominan disusun oleh mineral \\
lempung (coklat keruh) dengan sedikit butiran kuar- \\
sa dan mineral opak, yang berukuran lanau halus-pa- \\
sir halus (0,01-0,15 mm), dengan bentuk menyudut \\
tanggung-membundar tanggung. warna sayatan \\
kehitaman-kecoklatan, karena pembakaran sampel \\
batulempung agar sampel menjadi keras dan mudah \\
untuk dipreparasi menjadi sayatan tipis. \\
\hline
\end{tabular}

Gambar 12. Sayatan tipis batulempung (contoh P10) dari Desa Tompegunung

Secara mikroskopis diklasifikasikan sebagai batulempung (claystone) dengan tesktur klastik, terpilah baik, kemas tertutup, disusun oleh mineral lempung (95\%) dengan sedikit butiran kuarsa (2\%) dan mineral opak (3\%), yang berukuran lanau halus - pasir halus $(0,01-0,15 \mathrm{~mm})$, dengan bentuk menyudut tanggung-membundar tanggung (Foto 3.4). Lingkungan pengendapannya diperkirakan di zona Neritik dalam .

Contoh P2 (Gambar 13) di lokasi K. Sat (Ds. Gendongan) secara mikroskopis merupakan batulanau (siltstone). 


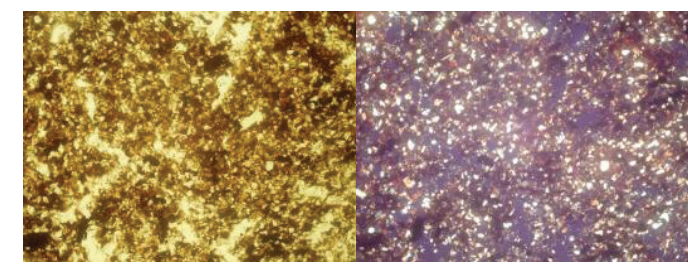

\begin{tabular}{|l|c|}
\hline // nicol & X nicol \\
\hline Sayatan Siltstone bertekstur klastik, terpilah \\
\hline
\end{tabular} baik, kemas terbuka, kontak antar butir point dan long contact, butiran terdiri dari kuarsa (putih granular, I6), k-felspar, mika, fragmen batulempung dan mineral opak; rata-rata berukuran lanau kasar $(0,05$ $\mathrm{mm})$, menyudut tanggung-membundar tanggung, tertanam di dalam matrik lempung (coklat keruh), porositas dissolution (C9, H3, I4).

Gambar 13. Sayatan tipis batulanau (contoh P2) dari K. Sat, Desa Tompegunung

Kenampakan mikroskopisnya berupa tekstur klastik, terpilah buruk, kemas terbuka, kontak antar butir point dan long contact, butiran (60\%) terdiri dari kuarsa (23\%), k-feldspar (14\%), mika (6\%), fragmen batulempung (10\%), glaukonit (4\%) dan mineral opak (3\%), berukuran lanau, menyudut tanggung - membundar tanggung tertanam dalam matrik lempung (30\%), semen mineral lempung $(5 \%)$ dan porositas $(5 \%)$ merupakan porositas dissolution. Lingkungan pengendapan neritik dalam. Proses diagenesis yang dapat diamati dalam sayatan tipis adalah:

- Kompaksi ditunjukkan oleh kontak antar butiran berupa point dan long contact serta mika yang bengkok

- Sementasi mineral lempung yang mengisi ruang antar butir

- Pelarutan pada butiran, matriks dan semen yang membentuk porositas dissolution

Batugamping dijumpai pada hasil pemboran inti BEG 3 dan BEG 6 dengan ciri berwarna putih kecoklatan, lapuk, ketebalan hingga $4 \mathrm{~m}$.

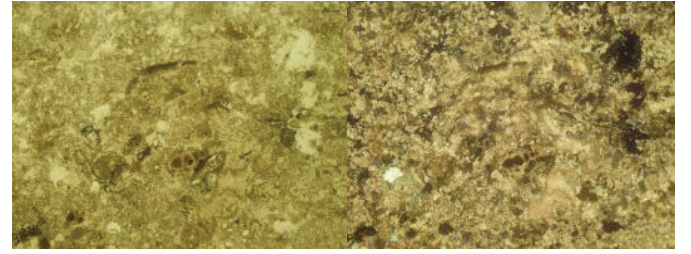

\begin{tabular}{|c|c|}
\hline // nicol & $\mathrm{X}$ nicol \\
\hline Sayatan Benthic Foraminifera Packstone \\
disusun oleh benthic foraminifera (G6, G7) \\
yang tubuh dan kamarnya diisi oleh glaukonit \\
(hijau) dan mineral opak (hitam) dan kuarsa \\
(B7), tekstur grain-mud supported; mikrit se- \\
bagian besar mengalami neomorfisme menjadi \\
microspar, porositas vuggy (K2, K5). \\
\hline
\end{tabular}

Gambar 14. Sayatan batugamping (contoh P7) dari inti bor BEG 3

Dari pengamatan mikroskopis, batuan ini dinamakan Benthic Foraminifera Packstone (Dunham,1962) (Gambar 14). Batuan ini disusun oleh butiran (55\%) yang terdiri dari benthic foraminifera, larger foraminifera, red algae, molusca, echinoderm, planktonic foraminifera, dan kuarsa. Butiran sebagian besar pecah, berukuran 0,03-2 mm, menyudut-membundar, tekstur grain-mud supported, terpilah buruk, kemas terbuka, kontak antar butir point-long contact. Butiran tertanam dalam matriks mikrit (5\%), semen $(25 \%)$ berupa sparry calcite (16\%), glaukonit (5\%) dan mineral opak (4\%). Tipe semen sparry calcite terdiri dari blocky, syntaxial overgrowth, micritic dan pendant. Porositas total 15\% terdiri dari porositas vuggy (12\%) dan moldic (3\%). Lingkungan pengendapan open lagoon (restricted inner shelf). Tahap diagenesis yang dapat diamati dalam sayatan tipis :

- Diagenesis pertama terjadi dalam lingkungan marine phreatic, yang ditandai oleh mikritisasi mikrobial dan sementasi glaukonit.

- Diagenesis kedua terjadi dalam lingkungan fresh water phreatic, yang ditandai oleh pelarutan yang membentuk porositas vug dan 
moldic, pelarutan pada tubuh fosil yang kemudian diisi oleh sparry calcite dan mineral opak, sementasi syntaxial overgrowth calcite pada echinoderma.

- Diagenesis ketiga terjadi dalam lingkungan burial, yang ditandai oleh neomorfisme mikrit menjadi microspar.

- Diagenesis keempat terjadi dalam lingkungan vadose, yang ditandai oleh pelarutan yang membentuk porositas vug dan moldic, dan sementasi sparry calcite (bertipe pendant).

Sayatan contoh batuan di Daerah Sumbersoka (contoh P13) (Gambar 15) dinamakan Feldsphatic Greywacke (Pettijohn, 1987).

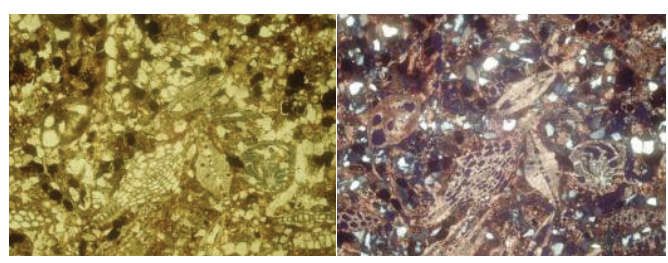

\begin{tabular}{|c|c|}
\hline$/ /$ nicol & $\mathrm{X}$ nicol \\
\hline $\begin{array}{l}\text { Sayatan Fe } \\
\text { klastik, terp } \\
\text { long, dan } \\
\text { terdiri dari } \\
\text { H6), benthi } \\
\text { raminifera } \\
\text { batulempun } \\
\text { rata-rata be } \\
\text { menyudut t } \\
\text { pung (cokla } \\
\text { konit, mine } \\
\text { rositas molc }\end{array}$ & $\begin{array}{l}\text { wacke, bertekstur } \\
\text { mas terbuka, point, } \\
x \text { contact, butiran } \\
\text { f foraminifera (F6, } \\
\text { G9), planktonic fo- } \\
\text { molusca, fragmen } \\
\text { ak dan ostracods; } \\
\text { kasar ( } 0,65 \mathrm{~mm}) \text {, } \\
\text { undar, matrik lem- } \\
\text { emen berupa glau- } \\
\text { an oksida besi, po- } \\
\text { dissolution. }\end{array}$ \\
\hline
\end{tabular}

Gambar 15. Sayatan tipis batupasir gampingan (contoh P13) dari inti bor BEG 3

Batuan ini bertekstur klastik, terpilah buruk, kontak antar butir point, long dan concaveconvex contact, butiran terdiri dari kuarsa (15\%), foraminifera besar (12\%), bentos (7\%) dan plangton (5\%), k-feldspar (5\%), molusca (4\%), fragmen batulempung (3\%), mineral opak (3\%) dan Ostracoda (1\%) berukuran lanau hingga kerakal, dengan rata-rata berukuran pasir, menyudut tanggung-membundar, tertanam dalam matriks lempung (20\%) dan semen berupa glaukonit (7\%), mineral lempung (2\%), oksida besi (1\%) dengan porositas total terdiri dari moldic dan dissolution. Lingkungan pengendapan neritik tengah. Proses diagenesis yang dapat diamati dalam sayatan tipis :

- Proses diagenesis pertama adalah kompaksi yang ditunjukkan oleh kontak antar butiran berupa point, long dan concavo-convex contact.

- Proses diagenesis kedua adalah deformasi yang ditunjukan oleh pemadaman bergelombang kuarsa monokristalin.

- Proses diagenesis ketiga adalah sementasi glaukonit, mineral lempung dan oksida besi yang mengisi ruang antar butir.

- Proses diagenesis keempat adalah pelarutan pada butiran, matriks dan semen yang membentuk porositas moldic dan dissolution.

2. Fm Bulu

Secara mikroskopis tidak terdapat perbedaan kandungan antara batugamping masif dan batugamping berlapis, kenampakan tersebut diduga akibat dari perbedaan energi pada saat pengendapan.

Berdasarkan hasil analisis laboratorium petrografi terhadap beberapa contoh batuan dari beberapa lokasi pengamatan di lapangan menunjukkan bahwa formasi ini dapat dikategorikan kedalam beberapa jenis batugamping berupa packstone dan grainstone (Dunham, 1962). Pembagian jenis batuan tersebut didasarkan pada ukuran dan jenis fragmen, matriks serta kristalisasinya.

Pengamatan mikroskopis contoh batugamping berlapis (Gambar 16) yang diambil dari lokasi Wonokusumo (contoh P8) adalah termasuk dalam kategori Larger foraminifera packstone. 


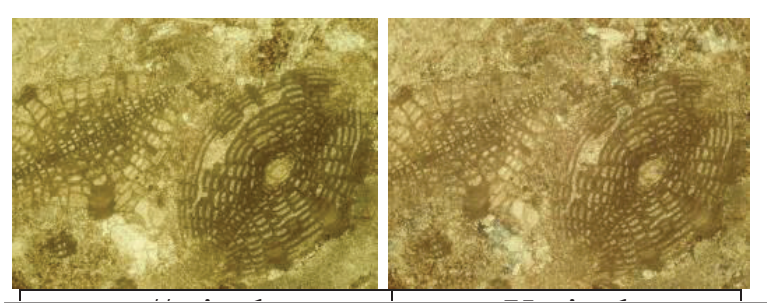

// nicol

$\mathrm{X}$ nicol

Sayatan Larger Foraminifera Packstone disusun oleh larger foraminifera berupa Lepidocyclina spp. (C5, I6) dan red algae (K9), tekstur grainmud supported; mikrit sebagian besar mengalami neomorfisme menjadi microspar, semen sparry calcite (putih, E8) dan mengisi kamar Lepidocyclina porositas vuggy (D7).

Gambar 16. Sayatan tipis batugamping (contoh P8) di Daerah Wonokusumo

Batuan ini disusun oleh butiran (55\%) terdiri dari larger foraminifera (25\%), red algae (9\%), molusca (7\%), coral (5\%), benthic (3\%) dan plankton foraminifera (1\%), echinoderma (3\%), ostracoda (1\%) dan kuarsa (1\%), terpilah buruk, kemas terbuka, kontak antar butir struktur stylolit dan sutured, tertanam dalam matriks mikrit (5\%), semen (25\%) berupa sparry calcite (18\%) (blocky, micritic, dan pendant), mineral opak (5\%) dan oksida besi (2\%), porositas terdiri dari vuggy dan fracture (15\%).

Dari hasil pengamatan mikroskopis tersebut di atas dapat disimpulkan bahwa batuan ini telah mengalami 4 (empat) tahapan diagenesis yaitu:

- Diagenesis pada lingkungan marine phreatic ditandai dengan mikritisasi mikrobial.

- Diagenesis pada lingkungan fresh water phreatic, yang ditandai oleh pelarutan yang membentuk porositas vug dan moldic dan sebagian diisi oleh sementasi sparry calcite, syntaxial overgrowth calcite pada echinoderma.

- Diagenesis pada lingkungan burial, ditandai oleh neomorfisme mikrit menjadi microspar, kompaksi yang membentuk kontak antar butir sutured.

Diagenesis lingkungan vadose yang ditandai pelarutan yang membentuk porositas vug dan moldic, sementasi sparry calcite (bertipe pendant) dan oksida besi.
Contoh batugamping masif (contoh P4) di daerah Goa Banteng (Gambar 17) yang mempunyai ciri fisik berwarna kuning coklat, kompak, sedikit berongga dan keras dan dalam kondisi lapuk berwarna kecoklatan termasuk dalam Red algae - Larger Foraminifera Grainstone (Dunham,1962).

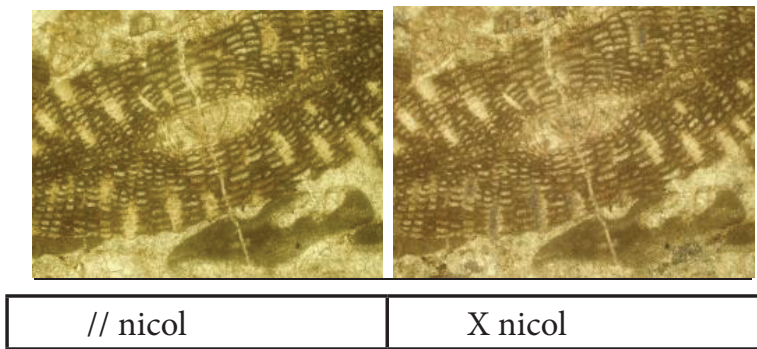

Sayatan Red Algae-Larger Foraminifera Grainstone disusun oleh larger foraminifera yang berupa Lepidocyclina spp. (K8, E8), dan red algae (H8), tekstur grain supported; semen sparry calcite bertipe blocky (putih) mengisi ruang antar butir, kamar Lepidocyclina spp. dan fracture.

Gambar 17. Sayatan tipis batugamping masif (contoh P4) di Daerah Goa Banteng

Batuan ini disusun oleh butiran berupa larger foraminifera (28\%), red algae (20\%), coral (4\%), benthic foraminifera (2\%) dan kuarsa (1\%) berbentuk menyudut tanggung hingga membundar. Tekstur grain supported, terpilah buruk, kemas terbuka, kontak antar butir sutured dan struktur stylolit. Matriks mikrit seluruhnya sudah mengalami neomorfisme menjadi microspar, semen berupa sparry calcite (26\%), mineral opak (4\%) dan oksida besi (2\%). Porositas total $13 \%$ terdiri dari vuggy dan fracture.

Tahap diagenesis yang dapat diamati dalam sayatan tipis adalah:

- Diagenesis pertama terjadi dalam lingkungan marine phreatic, yang ditandai oleh mikritisasi mikrobial

- Diagenesis kedua terjadi dalam lingkungan fresh water phreatic, yang ditandai oleh pelarutan yang membentuk porositas vug, pelarutan pada tubuh fosil yang kemudian diisi oleh sparry calcite. 
- Diagenesis ketiga terjadi dalam lingkungan burial, yang ditandai oleh neomorfisme mikrit menjadi microspar, kompaksi yang membentuk fracture dan stylolit.

- Diagenesis keempat terjadi dalam lingkungan vadose, yang ditandai oleh pelarutan yang membentuk porositas vug, dan sementasi sparry calcite (bertipe pendant), mineral opak dan oksida besi.

Hasil analisa petrografi dari contoh batugamping masif yang diambil di sekitar G. Gampingan dapat dikategorikan sebagai batugamping Coral Boundstone (gambar 18), yang mempunyai sifat fisik berwarna putih, poros, ringan, agak rapuh dan dalam kondisi lapuk berwarna kecoklatan.
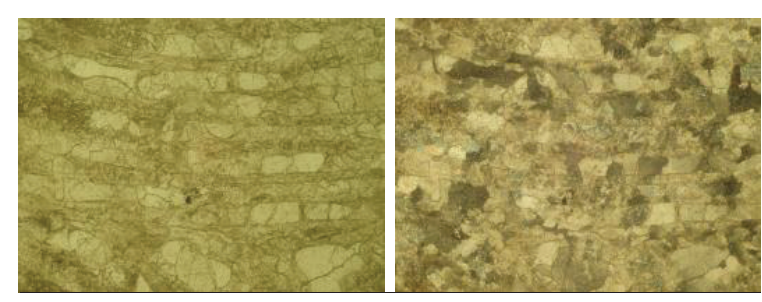

\begin{tabular}{|l|l|}
\hline \multicolumn{1}{|c|}{$/ /$ nicol } & $\mathrm{X}$ nicol \\
\hline Sayatan Coral Boundstone dominan disu- \\
sun oleh coral (F5) dengan tekstur bounded. \\
Coral berbentuk tabulate coral, ruang diantara \\
kamarnya diisi oleh mikrit, tubuh coral dan \\
mikrit mengalami neomorfisme menjadi mi- \\
crospar dan pseudospar, semen berupa sparry \\
calcite dan mineral opak (F6). \\
\hline
\end{tabular}

Gambar 18. Sayatan tipis batugamping masif (contoh P4) di Daerah Goa Banteng

Secara mikroskopis terlihat adanya tekstur: bounded (komponen organik asli terikat satu sama lain selama pengendapan). Ruang di antara coral diisi mikrit, red algae, echinoderma, foraminifera besar, molusca, bentos dan plangton foraminifera. Mikrit seluruhnya telah mengalami neomorfisme menjadi microspar, semen berupa sparry calcite, mineral opak, dan oksida besi. Porositas total 5\% berupa vuggy. Komposisi dari contoh batuan tersebut berupa fragmen kasar (75-80\%), terdiri dari fosil coral (67\%), red algae (2\%), echinoderma (2\%), foraminifera besar
(1\%), molusca (1\%), bentos (1\%) dan plangton foraminifera (1\%).

Secara diagenesis, dapat diterangkan bahwa pada batuan ini telah terjadi proses mikritisasi mikrobial dalam lingkungan marine phreatic. Diagenesis kedua terjadi dalam lingkungan fresh water phreatic, yang ditandai oleh pelarutan yang membentuk porositas vug, pelarutan pada cangkang fosil yang kemudian diisi oleh sparry calcite, sementasi syntaxial overgrowth calcite pada echinoderma, Diagenesis ketiga terjadi dalam lingkungan burial, yang ditandai oleh neomorfisme mikrit menjadi microspar dan pseudospar. Diagenesis keempat terjadi dalam lingkungan vadose, yang ditandai oleh pelarutan yang membentuk porositas vug, dan sementasi sparry calcite bertipe pendant.

\section{KESIMPULAN}

Berdasarkan hasil analisis petrografi dapat disimpulkan beberapa hal sebagai berikut:

1. Urutan stratigrafi di daerah penelitian dari yang berumur tua hingga muda adalah Formasi Ngrayong, Formasi Bulu dan Aluvium

2. Pada Formasi Ngrayong, satuan batuan yang dijumpai adalah perselingan antara batulempung, lanau, batugamping pasiran dan batupasir gampingan. Pada Formasi Bulu, batuan yang dijumpai adalah batugamping sedangkan aluvium terdiri dari kerikil, pasir, lanau dan lempung

3. Formasi Ngrayong diendapkan pada lingkungan neritik tengah hingga neritik dalam sedangkan Formasi Bulu diendapkan pada lingkungan inner shelf

4. Proses diagenesis yang terjadi pada Satuan Batuan Formasi Ngrayong umumnya adalah proses kompaksi yang dicirikan oleh kontak antar butir berupa point, long dan concavoconvex, sementasi mengisi ruang antar butir dan pelarutan yang menghasilkan porositas dissolution

5. Proses diagenesis yang terjadi pada Satuan Batuan Formasi Bulu umumnya adalah proses mikritisasi microbial di lingkungan marine phreatic, pelarutan yang membentuk porositas 
vug dan pengisian rongga di lingkungan fresh water phreatic serta di lingkungan burial terjadi neomorfisme mikrit menjadi microspar dan pseudospar.

\section{DAFTAR PUSTAKA}

Choquette, P.W. \& Pray, L.C., 1970, Geologic Nomenclature and Classification of Porosity in Sedimentary Carbonates. American Association of Petroleum Geologists Bulletin.

Dunham, R.J., 1962 Classification of Carbonate Rocks according to Depositional Texture. American Association of Petroleum Geologists.

Haryono, E., 2001, Nilai Hidrologis Bukit Kars, Makalah Pada Seminar Nasional EkoHidrolik, 28-29 Maret 2001, Jurusan Teknik Sipil, UGM.

Kadar, D., 1986, Neogene Planktonic Foraminiferal Biostratigraphy Of The South Central Java Area Indonesia, Geological Research and Development Center, Bandung, Indonesia.

Kadar, D. \& Sudijono, 1993, Peta Geologi Lembar Rembang, Jawa, Pusat Penelitian dan Pengembangan Geologi, Bandung.

Koesoemadinata, R. P., 1978, Geologi Minyak dan Gas Bumi, ITB, Bandung.

Moore, C.H., 1989, Carbonate Diagenesis and Porosity, Developments in Sedimentology, Elsevier Science Publisher, Amsterdam.

Pringgoprawiro, H., 1983, Stratigrafi cekungan Jawa Timur Utara dan Paleogeografinya: sebuah pendekatam baru, Disertasi Doktor. ITB (Tidak diterbitkan).

Tipsword, H. L., Setzer, F. M., \& Smith F. L. Jr., 1966, Interpretation of depositional environment in Gulf Coast petroleum exploration from paleoecology and related stratigraphy. Transaction G. C. Assoc. Geol. Soc: America

Tucker, M. E., 1991, Sedimentary Petrology: An Introduction to the Origin of Sedimentary Rocks, Blackwell Scientific Publication, Oxford, 2nd ed.

Suwarti, T., dan Wikarno, R., 1992, Peta Geologi Lembar Kudus, Jawa. Pusat Penelitian dan Pengembangan Geologi, Bandung. van Bemmelen. R. W., 1949, The Geology of Indonesia, v. I.A. Government Printing Office. 